\title{
DEKONSTRUKTIVIZMUS AZ ÉPÍTÉSZETBEN
}

\author{
BONTA JÁNOS \\ a múszaki tudomány doktora*
}

A dekonstruktivizmus a modern építészettel - amely az elemi tényezőkig nyúlt vissza - újrakezdett fejlódési görbe legújabb szakasza. Nem divathóbort, mint ahogy ma még sokan értetlenül fogadják, hanem a valóság természetéről, a hozzá füződő viszonyunkról nyert új ismereteink építészeti vetülete. Távlatból megítélve fellépése az építészet történetében, a modern avantgárd megjelenésénél is nagyobb és mélyebb megrázkódtatást idéz elő.

Eszmei, világnézeti hátteréről e rövid tanulmány csak néhány jellegzetes tényezőt idézhet fel. Világképének alapvonásait elsősorban a matematika és a fizika újabb meglátásai alapozzák meg - de távolról sem közvetlenül, hanem csak áttételesen, jelentős késéssel és sematikus formában, ahogy a tudományos eredményeket a köztudat feldolgozza.

A newtoni axiómák a napi tapasztalatoknak megfelelő tömegmozgások törvényeit foglalták rendszerbe. Ezek érvényességi körét tette viszonylagossá Albert Einstein általános és speciális relativitáselmélete. A mereven meghatározott világ körvonalainak további fellazulását vonja maga után a Heisenberg-féle határozatlansági összefüggés, amely szerint a mikroelemek helye és impulzusa egyidejüleg meghatározatlan; azaz a megfigyelés eszköze annak objektumát befolyásolja, ami a megismerés határaira mutat rá. És itt van továbbá a matematikai logika Gödeltétele, amely szerint minden axiómarendszerben létezik olyan állítás, amelyet az adott axiómákkal sem bizonyítani, sem cáfolni nem lehet. Valóságunk szerkezete - ezek szerint - a klasszikus logika törvényeivel nem ragadható meg teljesen.

A matematika, a fizika újabb eredményeinek hatására, és saját tapasztalataik nyomán a filozófiában, a történet- és társadalomtudományokban is mindinkább tu-

*A tanulmány szerzője a BME Építészettörténeti és Müemléki Tanszékének professzor emeritusa. Itt közölt cikke Modern épitészet - posztmodern épitészet c. kötetének egyik fejezete, amely az érvényes szerződés szerint 2001. év végéig jelenik meg a Terc Kft. Építőipar Szellemi Centrumának Lévai Kanyó Judit által vezetett Építőipari-Építészeti szakkönyvkiadója gondozásában. A szövegösszefüggéséből kiragadott fejezetet a szükséges mértékig kiegészítettük. 
datossá vált a felismerés, hogy a világ létformái nem írhatók le merev algoritmusokkal, mert megnyilatkozásaikban a véletlennek, az esetlegesnek, sőt a kaotikusnak is szerepe van. A nagy ideológikus narratívák (pestiesen szólva: a nagy mesék): politikai, gazdasági, szociológiai, művészeti hipotézisek sorra összeomlanak. Jean Derrida francia posztmodern filozófus közvetlenül a még létező és eszmélésünket bénító teóriák dekonstruálására szólít fel. A mechanikus merev rendszerek helyett, amelyek a világnak és az emberi természetnek nem képesek megfelelni, mozgékonyabb, rugalmasabb rendszerekbe vetjük bizalmunkat - a politikában, a gazdaságban például önszabályozó szabad piaci rendszerekbe. Az egységes világkép szétesik, s vele az egységesen értelmezendő történelem; sokféle világ van és sokféle történelem.

Mindezeknek az új felismeréseknek a modelljei a számítógépek nagy felbontási képességü monitorain úgy jelennek meg, mint hallatlanul bonyolult, előre nem számbavehető, de folyamatukban beteljesedő alakzatok (fraktálok), amelyek világunk valódi természetéhez közelebb állnak, mint a régi mechanikus modellek; rugalmasabbak, mozgékonyabbak amazoknál.

A világ természetéről kialakult új képzetek, a köztudat, a közérzet átalakulása mindenekelőtt a társadalom érzékeny szenzoraira, a művészetekre - közöttük a múvészi célú építészetre - hatott ki. Ez utóbbira oly módon, hogy évezredes struktúrájának fellazításával kifejezőeszközeit mai világunk szellemének és légkörének megidézésére szélesítette ki, gazdagította fel.

A változás lényegének érzékeltetéséhez néhány gondolattal a múltba kell visszaszállnunk. Schopenhauer szerint: „Tulajdonképpen a nehézkedés és a merevség harca a múvészi építészet egyedüli esztétikai anyaga: az a feladata, hogy ezt sokoldalúan és teljesen világosan napfényre hozza. E feladatát úgy oldja meg, hogy eme elpusztíthatatlan erőktől megvonja kielégítésük legrövidebb útját és kerülő úton elodázza a kielégítést és ezáltal a harc meghosszabbodik és mindkét erő kimeríthetetlen törekvése sokféle módon láthatóvá válik." A Schopenhauer által költőien leírt folyamat évezredeken át a függőleges nehézségi erők és az azokat kiváltó vízszintes erők rendszerében, az építészeti tektonikában öltött testet. Az építészet története - leegyszerúsítve - nem más, mint a tektonikus rendszer különféle szellemiséget megjelenítő megformálása. Története folyamán az építőművészet többségében szimmetrikus, kiegyensúlyozott eröket, megalapozott tekintélyt, kikezdhetetlen stabilitást sugárzó müveket produkált. Ez a tradicionális tektonika a mai világ leképzésére már nem alkalmas.

\footnotetext{
${ }^{1}$ Arthur Schopenhauer: Die Welt als Wille und Vorstellung. I. 430. old. Idézi Lukács György: Az esztétikum sajátossága. II. Tizennegyedik fejezet. Az esztétikai mimézis határkérdései. II. Az építőművészet. 419. old. Akadémiai Kiadó, Budapest, 1969.
} 
A földnehézségi erő nyilvánvalóan tovább is hat; az épületnek szilárdan állnia kell a földön. De a mai járművek, például repülőgépek, ủrjárművek megtervezéséhez használt computer-programok olyan alakzatok kialakítását és alkalmazását is lehetővé teszik, amelyek az építészeti alkotást kívülről áttekinthetetlen, instabil, dinamikus plasztikának, belülről rejtélyesnek, titokzatos labirintusnak mutatják, amelyben az ember elveszettnek, a mindennapokban érzékelt térviszonylatoktól különböző térvilágba tévedtnek érzi magát.

A dekonstruktivizmus lázadás minden intézményesült, elmeszesedett dogmával szemben: a klasszikus tektonika, sőt még a konvencionálissá laposodott posztmodern klasszicizmussal szemben is. A különböző koordinátarendszerekben kiteljesedő, hajlított, könnyedén lebegő elemek felszabadítják a képzeletet, s ez megrészegíti az embert, fantáziája szabadon csapong, játszik a véletlenszerúen eléje vetődő távlatokkal, töredékelemekkel.

A belső felszültségek, ellentmondások, váratlan asszociációk, paradox helyzetek minden müvészeti alkotásban megtalálhatók, nélkülük az élet teljessége nem idézhető fel. A dekonstruktivista építészet, amely áttört a merev tektonika keretein, ezáltal közelebb került a „szabad” képzőmúvészetekhez s olyan élményekben képes részesíteni, olyan hangulatokat képes felidézni, amelyekre eddig nem volt lehetősége.

Az építészeti dekonstruktivizmus szellemiségének körvonalazása után több felől eredő gyökereiről s különféle típusairól fogunk vázlatos áttekintést adni. A dekonstruktivizmus már felléptekor sem volt egységes irányzat; annyiféle, ahányan az épület dekonstruálásához hozzáfogtak.

E. M. Farrelly ${ }^{2}$ a Dada-mozgalomban fedezi fel a dekonstruktivizmus - ahogy ő nevezi az „Új Szellem” - előzményeit. „Munkamódszerük az automatikus technikára emlékeztet, amelyet Arp, Janko és Richter dolgozott ki dadaista kísérleteik során ... Ingatag és illanó formáik olyanok, mint Kurt Schwitzer Merzbaujának [hulladékelemekből összeállított építmény] mai változatai." Mind a Dada híveinek, mind az Új Szellem alkotóinak célja, hogy „... megtörjék a megtévesztés és önelégült köldöknézés megmerevedett sablonjait”, mélységesen megvetik az uralkodó építészeti rend „kánonjai előtti síma csúszó-mászó ... behódolást”. Fegyvereik ehhez a harchoz: ,az esetlegesség, véletlenszerüség és a szerencse, az anarchia és a töredékesség megjelenítése". ${ }^{3}$

Az Új Szellemmel rokon irányzat az USA-beli ,ad hoc” építészetben jelentkezett először. Gondolunk Bruce Goff Bavinger házára (1950-55), valamint Herbert Greene Prairie házára (1961). Mindkettő esetleges (talált) ipari hulladékelemeket használ fel organikus anyagokkal együtt, egységes kompozíciót alkotva. A gondo-

\footnotetext{
${ }^{2}$ E. M. Farrelly: The New Spirit. In: Architectural Rewiew, 1986/8.

${ }^{3}$ Az idézetek a tanulmány szerzőjének fordításai, i. m. 3 .
} 
san megtervezett épület barkácsoltnak, befejezetlennek hat. Susan Sontag szerint: „Kísérlet az ipari civilizáció termékének természeti álomképpé varázslására”.

Az USA-beli dekonstruktivizmus előzményei között kell megemlítenünk, a később az irányzat vezető mesterének minősülő Frank O. Gehry saját házának, egy zsindelytetős, téglakéményes idillikus viktoriánus hajléknak hullámbádog falakkal, drótkerítéssel, modern üveg kubusokkal kibővített változatát, amely ily módon kiegészülve otthonosság helyett az instabilitás drámáját jeleníti meg (Santa Monica, 1978/79).

Nyers ipari hulladékelemek, konténerek felhalmozásával, amelyeket csövekkel, futószalagokat rejtő hidakkal kapcsol össze, építi meg John Johansen a Mummers Theatert, amely úgy hat, mintha elemeit különböző roncstelepekről válogatták volna össze. A High-Tech-hel szemben ez a Low-Tech (Oklahoma City, 1970). A példák szaporíthatók volnának.

Európában a dekonstruktivizmus előzményeinek a Participation-mozgalom keretében a lakók, a használók közremúködésével ad hoc megoldásokkal készült alkotások tekinthetők. Szélsőséges példájuk Lucien Kroll Orvosi Egyetemi épületei (Louvain, 1970/76). A tervező minden építési programmal, bürokratikus előírással szembeszállva teljes szabad kezet adott a hallgatóknak. Az eredmény: az épület a hallgatói igények sokféleségét jeleníti meg megszületésük még forrongó állapotában betonba, kőbe, téglába fagyasztva. Az anyagoknak, formáknak, ötleteknek fésületlen sokasága szétfeszíti a hagyományos építészeti rend kereteit, azaz dekonstruálja az épületet.

Az első valóban dekonstruáltnak ható épületek, legjobb tudomásom szerint, Ausztriában jelentek meg. Günther Domenig Z-Bank-ja (Bécs, 1975/79) az építészeti tektonika törvényeit semmibevevő épületet ábrázol, amennyiben összeroskadó félben mutatja magát, ami hatásos dadaista fricska a konvencionális építészet orrára.

Farrelly az Új Szellem legautentikusabb képviselőit a Coop Himmelblau irodának a 80-as években készült terveiben ismeri fel: The Red Angel kisszínház (Bécs, 1980/81), Atelier Baumann (Bécs, 1984/85) stb. A világhírt a cégnek azonban csak újabb múvei hozták el. Az ügyvédi iroda bővítése tetőtérben (Bécs, Falkenstrasse, 1983/85) már igazi dekonstruktivista mủ. Egy historizáló épület tetőzetét szakítja meg és nyitja fel. A lendületesen magasba ívelő és a fôpárkány elé lelógó fémrudak, redőzött lemezek, ívelt ablakok levegős munkahelyeket teremtenek a sokkoló hatású felépítmény belsejében. A Funder gyár 3-as üzeme (St. Veit Glan, Karinthia, 1988/89) mühelyépületének sarkai előtt „táncoló” fémesen fénylő kéményhengerek könnyeddé, vidámmá hangolják a különben közönyös ipari csarnokot.

A dekonstrukciónak emblematikus múvét alkotta meg az iraki származású, Londonban élő Zaha Hadid (Vitra Túzoltóállomás, Weil am Rhein, 1993). Saját le- 
írása szerint három sugárba rendezi el épületét, amelyek közül az első nyílegyenesen fölémeredő lemeztetővel fogadja a látogatót. Az épület egésze kirobbanásra kész rakétának hat. Hasonló dinamikáról árulkodik lakó- és kereskedelmi épülete is (Berlin, Kreuzberg, Stresemannstrasse, 1987).

Az Új Szellem építészetének úttörője írásaival és grafikáival is Rem Koolhaas. Épületei nem annyira szerkezetükkel, mint eredeti anyag- és színhasználatukkal képviselik az Új Szellemet. Legjobb példa erre a Grand Centre for Art and Mediatechnologie (Karlsruhe, 1990) terve, amely a látványt, a szín- és fényhatásokat bontja fel; az épületről nyert vizuális élményt dekonstruálja.

A dekonstruktivizmus szelleméhez közel áll a Parc de la Vilette (Párizs, 1982) tervezője, Bernard Tschumi, aki a rendelkezésre álló területre egy négyzethálót fektetett fel, melynek csomópontjaira „Bolondságokat” (Folies) helyezett. Bár bizonyos rendeltetésük is van, ezek lényegükben konstruktivista-dadaista plasztikák, melyeket bíborvörösre festetett és „talált" gépelemekből szereltetett össze. A Parc de la Vilette területi terveinek elkészítésével kezdődik meg Tschumi, Eisenman és a filozófiai dekonstruktivizmus kezdeményezőjének, Jean Derridának együttmúködése.

Az USA-beli dekonstruktivizmus közvetlen előzményei a „New Yorki Ötök” közül John Hejduk, Michael Graves és Peter Eisenman kísérletei az alaprajzok elforgatásával. Hejduk „Gyémántházai” (1967) a 90 fokos elforgatással kialakítható dinamikus kompozíciók lehetőségeit kutatják. Graves e csoportba soroló házai közül a Snyderman House (Fort Wayne, 1972) teoretikus indíttatású, hermetikus geometriájával mutat a dekonstruktivizmus irányába. Kísérleteit Peter Eisenman folytatja a „House I-től a House El Even Odd-ig”. A House III-nál (Miller House, Lakeville, 1969/70) két egymáshoz képest 45 fokban elforduló négyzetet metsz egymásba és áttört falakkal, födémekkel minden eddiginél bonyolultabb átlátásokat, áthatásokat idéz elő. A bonyodalmakat, a hatást még funkcióellenes trükkökkel fokozza. A House VI for the Franks (Washington, 1975) épületében bíborszínú virtuális lépcsővel zavarja meg a szemlélöt. De Eisenman még a családi élet dekonstruálására is merészkedik, amikor a szülői hálót egy nyílással helyettesített oszloppal, s annak nem létező árnyékával, azaz a födém áttörésével megnyitja az alatta elhelyezett nappali felé, a két szülői ágy közé szakadékot teremtve. Charles Jencks szerint ezzel a nem kívánt babáról szól.

A családi házakkal folytatott geometriai kísérletek tovább már alig fokozható határát Eisenman Guardiola-ház terve éri el. A tervező nem csak alaprajzban, hanem a szintek között is elcsúsztatásokkal, elforgatásokkal él, sőt a függőlegesvízszintes rendszerből is kilép. Ily módon a tektonikus-ortogonális rendszer szinte teljes dekonstrukciójáig érkezik el.

Életmúve során Eisenman egyre következetesebben jut el a tektonikus rendszer teljes dekonstruálásáig. Ezzel „... az építészetet óhajtja megfosztani a vizuális be- 
idegzésektől, meggyökeresedéstől, társadalmi be- és elfogadástól - sőt a szeretettől is."

Eisenman középülettervei során a dekonstruálás különféle fokozatait, lehetőségeit, válfajait mutatja be. A Wexner Centernél (Columbus Egyetem, 1983/89) a már ott állott épületeket egy átlósan végigvezetett térrácsszerkezet közbeiktatásával integrálja egységbe; a dekonstrukció csak részletekben van jelen: felhasított lőportorony, befejezetlen boltív, lépcsőre támaszkodó, mennyezetről lógó pillér stb.

A Cincinnati Project a következő lépés a teljes dekonstrukció felé. Eisenman az itt talált épületeket egy karéjalakú tömbbel egészíti ki, amelyet ..., ,egy ráncolt (folded), meg-meg torpanó, törődött membrán” követ. „A belsőben nincs vízszintes, illetve függőleges felület ... az egész olyan, mint egy tektonikus mozgásoktól megredősödött barlangbelső." A tartószerkezet azonban nem képes a töredezettség és az ortogonális rendből való ilyen fokú eltérés követésére. Amit közvetlenül érzékelni tudunk: pasztell színekre festett kartonlemezek. A valóságos tektonika teljes elszakítását az érzékelhető látványtól nem ítéljük jövőbe mutató megoldásnak. De nem tủnik biztatóbbnak a Nunotani Corporation székházának (Tokió, 1988/90) megoldása sem, ahol a ferdén lecsúszó homlokzatok mögül előtünik az ortogonális vasbeton váz.

A columbusi Convention Center (1989/93) hatalmas fötermét Eisenman különféle magasságú hajlított csíkokra szabdalja. A felszabdalás indoka feltehetően a hatalmas méretek nyomasztó hatásának feloldása. Ennek ára viszont a nyolc pillér, ami a nagyteremben - tömegrendezvények esetében - az átlátást zavarja. A nagyterem lefedésének felszabdalásában Eisenmant a Gilles Deleuse, francia filozófustól átvett „Pli” (Folding) azaz hajtogatás módszere is befolyásolta. A belső utak megtörtek, különféle magasságúak, olykor ferde szerkezeti elemekkel határoltak, mozgalmas, izgalmas távlatokba vesznek. A dekonstrukció itt valóban a végtelen méretek unalmát ellensúlyozza.

Néhány mondattal a Pli, a Folding gondolatára visszakanyarodva. Deleuse koncepcióját a japán origami múvészetre vezeti vissza, ahol egy-egy papírlapból pusztán hajtogatással bármilyen alakzat előállítható, legalábbis annak közeli modellje. Deleuse viszont ,...egyszerúen mindent - a kozmoszt, az emberi lelket, a müvészetet, a matematikát, sőt az organizmusokat is - valami egyetemes és egyben végtelenül differenciált hajtogatás eredményének tekinti. ${ }^{6}$ Ez nehezen hihető: mechanikus művelettel nem alkotható élő organizmus. Deleuse koncepciójának megítélése a filozófusok feladata; bennünket építészeti alkalmazásának kérdésessége foglalkoztat. Bár inspiráló hatása kétségtelen.

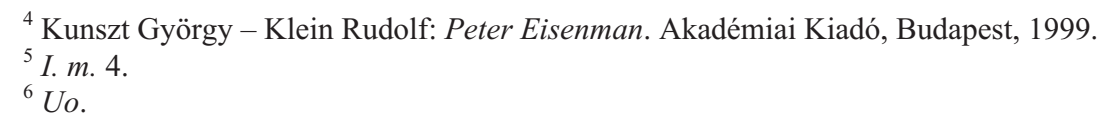


A folding eszméjének hatásáról árulkodó legjelentősebb Eisenman-terv a Max Reinhard Haus (Berlin, 1992). Két, közel 50 emeletes, sokszorosan megtört, megcsavart torony a magasban összenő, és egymásba megy át. „A csúfság redői (foldjai) között mozogva valamiféle bizarr és monumentális szépség igézetébe kerülünk." ${ }^{7}$

Még egy a folding szellemében fogant és elkészült épületről szólunk: Daniel Libeskind Zsidó múzeumáról (Berlin, 1988). Sokszorosan megtört tömege, a tengelyek és szimmetriák teljes hiánya dezorientálják a látogatót, kizökkentik megszokott világából, amit a múzeum tartalma teljes mértékben indokol.

Végső fokon a folding nem más, mint a dekonstrukció egyik válfaja. Módszer a sok ezeréves beidegződések megzavarására. Célja, hogy megfossza az embert az áttekinthető világ illúziójától, az építészetben a vízszintesek és függőlegesek egyeduralmától és helyébe egy titokzatos, kalandokkal kecsegtető, olykor félelmetes, elveszejtő környezettel vegye körül.

Közben tovább fejlődött a Dada-mozgalom csíráiból kibontakozott, a Farrelly által felismert és az Új Szellem megnyilatkozásaként üdvözölt alkotási mód is, amely a tudatalattiból merítő intuitív alkotás öröméhez, a váratlan, meglepő, a befejezetlen életszerü szépséghez talál utat.

Legjelentősebb alkotóművésze: Frank O. Gehry. A 80-as években Gehry különféle anyagú, színű, különféle formavilágokat képviselő épületekből alkot együtteseket, amelyek a spontán módon kialakult esetleges, sőt csúnya kisvárosi szövetre emlékeztetnek. Különösképpen adekvát módszere üzletközpontoknál, amelyeket városnegyedekre dekonstruál. Az üzleteket, vendéglőket, szórakozóhelyeket girbe-görbe utcák, kis terek, udvarok mentén helyezi el, s ily módon egy spontán módon kialakult kisvárosi negyed életteli, mozgalmas légkörét teremti meg (Edgemar Center, Santa Monica, 1988).

A 90-es évek Gehryje tovább halad a tudatalattiból merítő automatikus alkotás irányába, s félig hunyt szemmel, könnyed kézzel, puha ceruzavonásokkal lendületes görbéket vázol fel, melyek realizálása csak rendkívül komplikált számítógépes programokkal lehetséges. Az első ilyen organikus alakzatokra emlékeztetően minden irányban görbült elemekből tervezett épülete a Walt Disney Concert Hall (Los Angeles, 1992), bár több modell és vázlat is készült róla - az említett nehézségek miatt építése félbemaradt. A Toledo Art Building (Ohio, 1990/92) olyan, mintha óriások brutális sziklákat dobáltak volna egymásra. Ellentmondás, hogy a sziklákat horganyzott réz borítja. Gehry épületei olyanok, mintha mozgás közben hirtelen merevedtek volna meg.

Végül eljutottunk Gehry pályájának - s talán az egész korszaknak - csúcsteljesítményéhez (méretben feltétlenül), a Solomon R. Guggenheim Modern Müvésze-

${ }^{7} \mathrm{Uo}$. 
tek Múzeumához (Bilbao, 1997). Néhány jellegzetes adat, illetve körülmény: a területen ível át a város egyik legfontosabb közlekedési hídja, a Puente de la Salve, amelyet Gehry a kompozíció részévé tett. Az épület alapterülete: $25000 \mathrm{~m}^{2}$. Központját egy $50 \mathrm{~m}$ magas atrium alkotja. Ez a kiállításokat látogatók kiindulópontja. Az atrium köré szerveződik a három galériaszint. Az innen szétágazó kiállítási tömböket hidak, üvegliftek, lépcsőtornyok kapcsolják a központhoz. A leghatalmasabb kiállítási tér egy hajó formájú, $130 \times 30$ m méretü galéria, amely a régi híd alá is benyúlik. Az egyes tömbök is hajlított, görbült alakúak, és mint egy dombvidék, magasodnak egymás fölé. A kompozíció csúcspontját a titán anyagú, görbült, csavartformájú „kupola” alkotja. A jármüvekre, természeti alakzatokra emlékeztető formák építészeti kialakításához repülőgépépítéshez használatos háromdimenziós computer-programokat kellett igénybe venni. A bilbaói Guggenheim múzeum épülete minden eddigi építészeti alkotástól eltérő formavilágot és kompozíciós módszereket képvisel. A tervező művészi célja, hogy a megmerevedett hagyományos tektonikát meghaladja, $\mathrm{s}$ a mi ismereteink szerint szilárdan nem körvonalazható világképünk építészeti modelljét megmintázza. A tektonika, a függőlegesek és vízszintesek eligazító rendje helyett csupa görbült felület övezi körül a látogatót, aki úgy érzi magát, mintha kilépett volna megszokott világából s egy bizonytalan térbe tévedt volna bele.

A dekonstruktivista műveket korai lenne mereven elutasítani vagy maradéktalan lelkesedéssel üdvözölni, mert a jövő ajtajait nyitogató kísérletekkel állunk szemben, melyekről jelen pillanatban nem mondható még meg: vajon tartós befolyást fognak-e gyakorolni az építészet jövőbeni fejlődésére, vagy csöndesen elfelejtődnek, mint amilyen megdöbbentő sebességgel avulnak a klasszicizáló posztmodern kísérletek? Szubjektív megítélésünk szerint a dekonstruktivisták korunk világérzését mélyebben érezték át, mint a szük értelemben vett posztmodernek, s talán a jövőből is többet sejtettek meg amazoknál. Következésképpen nem tévedünk nagyot, ha feltételezzük, hogy kísérleteiknek némely - a kor világképével szinkron vonása - a jövő építőmüvészetében is meg fog jelenni.

\section{DECONSTRUCTIVISM IN ARCHITECTURE}

\section{Summary}

\footnotetext{
The scientific recognitions of the last decades have spectacularly changed our mind about the feature of reality, and our relations to it. We have found out, that it is not possible to determinate the processes of the reality with rigorous axiom, since the accidental, the occasional, morever the chaos are inherent parts of it. The change of the world-concept deprives the man from the illusion of a determined world, and placed him in an instabil, confused, mysterious environment. The new wave of architecture discontinues the historical autocracy of horizontal and vertical elements, and deconstructs the tectonical and orthogonical system.
} 
The author presents different ways of how to deconstruct buildings. This trend in Europe is rooted in the Dada Movement, in his automatical method, experimented by Arp, Janko, and Richter. Among the first deconstructivist buildings are the works of the firm Coop Himmelblau in Vienna.

This movement in the USA was set out by the New York Five, especially with the works of Peter Eisenman, who turned plans and grids of buildings in two contrary directions at $45^{\circ}$, the walls-holes and crossing frames duzzles the eye, confuses the mind. Step by step Eisenman approaches to fully deconstruct the conventional image of a building. This process culminated in his project Max Reinhard House in Berlin, in adaption of the Folding method.

Another great American architect of deconstructivism is Frank O. Gehry, whose works rooted also in the Dada. His ancestors were Kurt Schwitzers Merzbau, and the works of "ad hoc" architects in the USA. Gehry sketches the concept of his building in large, with free hand issued from the subconscious. Hence his indistinct and organic forms could be realized only through complicated computer programmes, used by airplane projecting. His last work: the Salomon Guggenheim Museum of Modern Arts in Bilbao with its radical new shape of spaces and volumes recalls the new world-concept.

Keywords: deconstructivism, Frank O. Gehry, Peter Eisenman 
